\title{
PEMBELAJARAN DAN PEMEROLEHAN BAHASA ARAB DI PONDOK MODERN GONTOR DI DARUL MA'RIFAT GURAH KEDIRI JATIM
}

\author{
Siti Jubaidah \\ Universitas Negeri Jakarta
}

\begin{abstract}
:
Keywords:

Abstrak: penelitian ini bertujuan untuk memperoleh pemahaman dan gambaran mendalam tentang pembelajaran dan pemerolehan bahasa Arab di pondok modern Gontor III. Penelitian ini dilaksanakan di pondok modern Gontor III Darul Ma'rifat Gurah Kediri Jatim dan dilaksanakan selama kurang lebih 1 tahun, sejak Agustus 2013 sampai dengan Juli 2014.

Pembelajaran dan pemerolehan bahasa Arab di pondok modern Gontor III dapat dikatakan baik karena budaya lingkungand an kegiatan kebahasaan yang ada di sana seperti adanya laboratorium bahasa alami berupa lingkungan wajib berbahasa pondok baik berupa bahasa Arab selama seminggu (Al-Usbu'alAraby) dan bahasa Inggris (Al-Usbu' al-Injilizy) dengan didukung oleh disiplin berbahasa yang ketat.

Hasil penelitian ini secara teoritik berguna untuk pengembangan ilmu pendidikan khususnya pengajaran Bahasa Arab, sebagai masukan bagi Pondok Modern Gontor III Darul Ma'rifat, khususnya dalam mengembangkn pola pembelajaran bahasa Arab dan sebagai acuan bagi pesantren maupun lembaga pendidikan lain yang ingin membekali materi-materi acuan bagi pesantren maupun lembaga pendidikan lain yang ingin membekali materi-materi dan skill kebahasa-Araban santrinya, pesantren yang menggunakan metode pembelajaran bahasa Arab yang efektif dapat dijadikan rujukan dan menjadi salah satu penunjang dalam pengajaran bahasa Arab di pesantren itu sendiri dan dunia perguruan tinggi terutama bagi UNJ, UIN, IAIN, STAIN dan universitas-universitas lainnya yang mutu input mahasiswa dan out put lulusannya sangat bertumpu pada mutu dari lulusan lembaga pesantren.
\end{abstract}

Kata kunci: pembelajaran, pemerolehan, al-Usbu'al-'araby, al-Usbu'al-Injilizy

\section{PENDAHULUAN}

Sebelum Islam, bahasa Arab telah dikenal sebagai bahasa suku bangsa Quraisy yang oleh suku-suku bangsa Arab lainnya tidak diketahui dengan baik, karena bangsa Arab itu terdiri dari banyak suku bangsa yang bahasannya tidak selamanya sama (Nasution, 1996: 310-311). Setelah Islam datang bahasa Arab mengalami perkembangan yang demikian pesat seiring dengan pesatnya proses penyebaran Islam dan proses perkembangan ilmu pengetahuan melalui fase penerjemahan karya-karya ilmiah dari berbagai bahasa ke dalam bahasa Arab (Nasution, 1996, 314). Mastuhu (1994: 20) menyimpulkan bahwa bahasa Arab telah berkembang sejak awal masuknya Islam ke wilayah Nusantara dan terus "melaju dan terlestarikan" dengan adanya pondokpondok pesantren sejak pesantren dikenal di bumi Nusantara ini, yaitu sejak abad ke 1317 M dan di Jawa pada sekitar abad 15-16 M.

Sejalan dengan makin meningkatnya kedudukan dan peranan bahasa Arab di dunia Islam khususnya dan dunia 
Internasional umumnya, apalagi bahasa Arab merupakan kunci yang sangat diperlukan untuk mengungkap peninggalanpeninggalan Islam yang penuh dengan khazanah peradaban dan ilmu pengetahuan (Hidayutallah, 1991: 138), maka usaha mencari metode pengajaran bahasa Arab yang tepat, praktis dan sistematis serta efisien terutama bagi bangsa-bangsa nonArab sangatlah penting. Selain itu karena bahasa itu mencakup aspek ilmu kebahasaan dan aspek ketrampilan berbahasa baik lisan maupun tulisan, maka penguasaan keduaduanya merupakan suatu tuntutan di zaman globalisasi sekarang ini karena itu metode pengajaran yang digunakan juga harus memperhatikan dan menekankan kedua aspek tersebut.

Penerapan metode baru dalam pengajaran bahasa Arab di PM. Gontor mulai dilaksanakan sejak tahun 1936, yaitu sejak kembalinya KH. Imam Zarkasyi dari sekolah Normal Islam di Padang dalam rangka memperdalam ilmu dan mencari alternatif sistem pendidikan pesantren modern dan studi perbandingan dengan Normal Islam yang dipimpin oleh Syekh Mahmud Yunus.

Sejak saat itu Pondok Modern Gontor menjadikan bahasa Arab sebagai bahasa pengantar dalam proses pendidikan dan pengajarannya, sedang bahasa Inggris juga digunakan sebagai bahasa pengantar dalam materi yang berkaitan dengannya. Sejak saat itu, PM. Gontor adalah salah satu pondok pesantren yang konsisten menerapkan al-Thoriqah al-Mubasyarah dalam pengajaran bahasa Arab dan Inggris di Indonesia hingga saat ini. Pesantren ini telah berhasil mengeluarkan ribuan alumni yang berasal dari seluruh Nusantara yang memiliki kemampuan berbahasa yang relatif baik. Para alumninya juga telah berpartisipasi dalam proses penyebaran metode pengajaran bahasa di darahnya masing-masing dan di pondok-pondok yang mereka dirikan.

Sebagai sebuah lembaga pendidikan pondok pesantren, di PM. Gontor dikenal adanya Panca Jiwa Pesantren yang berisi lima prinsip dasar dalam menjalankan pendidikan dan pengajarannya sejak 80 tahun terakhir. Di PM. Gontor bahasa Arab dan Inggris merupakan bahasa resmi yang harus digunakan dalam pergaulan para guru dan Kyai, para penyelenggara pendidikan yang ada di dalamnya terutama bagi seluruh santri dalam aktifitas kehidupan mereka sehari-hari, sehingga pondok tidak lain bagaikan laboratorium bahasa alami (alMa'mal al-Lughawi al-Thabi'i). Keduanya dianggap sebagai mahkota kebanggan pondok yang harus dilestarikan dan dikuasai karena keduanya merupakan kunci ilmu pengetahuan dan teknologi modern. Hanya dengan penguasaan keduanyalah usaha membangkitkan dunia Islam dapat dimulai. Dan PM. Gontor sedikit banyak santrinya telah diakui berhasil dalam pemerolehan dan pembelajaran bahasa Arabnya termasuk di dalamnya penerapan metode pengajaran bahasanya.

Berangkat dari sinilah penulis merasa tertarik untuk meneliti tentang pembelajaran dan pemerolehan bahasa Arab di Pondok Modern Gontor III Darul Ma'rifat Gurah Kediri dalam usaha membimbing santri-santrinya menguasai keterampilan (skill) berbahasa Arab di bidang Takallum/Muhadatsah (berbicara) dan Insya (mengarang). Tingkat efektivitas metode yang diambil akan dinilai melalui analisa hasil persepsi santri terhadap penerapan metode yang digunakan oleh para guru (ustadz) di kelas tiga biasa, dan hasil belajar dalam bentuk nilai bahasa Arab santri yang terfokus pada aspek keterampilan berbahasa berupa Takallum/Muhadatsah (berbicara) dan Insya (mengarang). 
Alasan penulis memilih PM. Gontor III Darul Ma'rifat yang terletak di Desa Sumbercangkring Kecamatan Gurah Kabupaten Kediri Jawa Timur, untuk menjadi obyek penelitian ini adalah karena obyek lokasinya lebih memungkinkan untuk kami jangkau dan kami merasa mudah untuk mendapatkan izin penelitian di pondok tersebut. Selain itu PM. Gontor III Darul Ma'rifat berada di antara sekian banyak pondok pesantren salafi yang mayoritas dari warga Nahdatul Ulama. Secara umum penelitian ini bertujuan untuk mengetahui proses pembelajaran dan pemerolehan bahasa Arab yang dikembangkan di Pondok Pesantren Modern Gontor.

\section{METODOLOGI PENELITIAN}

Penelitian ini menggunakan pendekatan kualitatif dengan metode etnografi. Secara khusus penelitian ini bertujuan untuk mendeskripsikan pembelajaran bahasa Arab yang dikembangkan di Pondok Modern Gontor Tiga Darul Mar'rifat, mendeskripsikan pelaksanaan pemeroleh bahasa Arab yang di dapat oleh santri di Pondok Modern Gontor Tiga Darul Ma'rifat. Tempat yang menjadi lokasi objek penelitian bagi peneliti adalah Pondok Pesantren Gontor III Darul Ma'Rifat Gurah Kediri yang beralamat di desa Sumber cangkring Kecamatan Gurah Kabupaten Kediri. Waktu penelitian dimulai bulan Agustus 2013 sampai dengan Juli 2014. Penelitian ini menggunakan pendekatan kualitatif dengan metode etnografi.

Peneliti menggunakan langkahlangkah analisis data yang diajukan Spradley: 1) memilih sebuah situasi sosial, 2) melakukan pengamatan terlibat, 3) membuat catatan lapangan, 4) melaksanakan pengamatan deskriptif. 5) melakukan pengamatan terfokus, 6) membuat analisis taksonomi, 7) melakukan pengamatan terpilih, 8) membuat analisis komponen, 9) membuat analisis tema, 10) membuat catatan teori, 11) membuat teori kualitatif (sebuah etnografi).

Teknik pengumpulan data yang digunakan adalah teknik pengamatan. Teknik pengamatan dalam penelitian ini dilakukan baik dengan partisipasi maupun nonpartisipasi. Teknik pengamatan dilengkapi dengan perekaman dan pencatatan lapangan. Sedangkan prosedur pengumpulan data menggunakan observasi, yaitu teknik pengumpulan data yang dilakukan secara terencana dan disengaja dimulai dengan pengamatan dan pencatatan terhadap gejala-gelaja yang diselidiki. Yaitu tentang proses pembelajaran dan pemerolehan bahasa Arab; interview (wawancara). Karena penelitian ini berupa penelitian etnografi, maka pedoman wawancara yang tepat untuk digunakan adalah pedoman wawancara tak terstruktur; dokumentasi dimana teknik ini digunakan untuk mengumpulkan data dari sumber yang non-insani, yang terdiri dari dokumen dan rekaman

\section{HASIL DAN PEMBAHASAN}

Pembelajaran Bahasa Arab di Pondok Pesantren Modern Gontor III Darul Ma'rifat Gurah Kediri

Kurikulum KMI terdiri dari ilmu pengetahuan agama dan ilmu pengetahuan umum. Pengeturannya diintegrasikan dengan sistem Pondok Pesantren; santri hidup selama 24 jam dalam asrama di bawah bimbingan guru dan Kyi. Maka kurikulum KMI tidak terbatas pada pelajaran di kelas saja, melaikan keseluruhan kegiatan di dalam dan di luar kelas merupakan proses pendidikan yang tak terpisahkan. Pada bagian ini akan dibahas kegiatan intra kurikuler (akademik) dan kegiatan-kegiatan ekstra-kurikuler (non-akademik).

\section{Kegiatan Intra-Kurikuler}


Penanggung jawab kegiatan bidang intra-kurikuler adalah lembaga KMI yang dipimpin oleh seorang direktur dan dibantu oleh beberapa staf dari guru (ustadz). Di lembaga KMI terdapat dua macam program yang ditempuh oleh santri yang berbeda berdasarkan latar belakang jenjang pendidikan mereka sebelum masuk pondok. Dua macam program itu adalah program reguler enam tahun dan program intensif empat tahun. Program reguler enam tahun adalah program yang diperuntukkan bagi siswa lulusan SD/MI dengan masa belajar enam tahun dan ditempuh secara berurutan dari kelas 1 sampai kelas 6, kenaikan kelas ke kelas yang lebih tinggi dilakukan setelah menempuh ujian semester pertama pertengahan tahun (biasanya diadakan pada bulan Shafar) dan semester kedua pada akhir tahun (biasanya diadakan pada bulan Sya'ban). Sedangkan program intensif adalah program yang diperuntukkan bagi siswa lulusan sekolah lanjutan (SMP/MTS dan di atasnya) dengan masa belajar empat tahun dengan urutan kelas I, III-intensif, V, dan VI. Bagi santri yang pernah belajar di pondok-pondok alumni gontor ataupun pondok lainnya dapat mengikuti ujian kenaikan ke kelas yang lebih tinggi sesuai dengan kemampuannya yang biasanya diadakan pada semester pertama (awal tahun).

Tujuan institusional umum dari kurikulum KMI adalah mencetak santri yang mukmin muslim, taat menjalankan dan menegakkan syari'at islam, berbudi tinggi, berbadan sehat, berpenngetahuan luas, berpikiran bebas dan berkhidmat kepada bangsa dan negara.

\section{Kegiatan Eksta-Kurikuler}

Kurikulum kegiatan ekstra-kurikuler ini ditangani oleh staf bagian pengasuhan santri melalui organisasi santri (OPM) dan koordinator gerakan pramuka. Kegiatan santri itu reintegrasi dalam bentuk kegiatan harian, mingguan, tengah tahunan, dan tahunan.

\section{Strategi Pembelajaran Bahasa Arab di Pondok Modern Darul Ma'rifat}

Hal yang mencakup strategi pengajaran yang dilakukan Pondok Modern Darul Ma'rifat mencakup metode, kaidahkaidah dan langkah-langkah, penilaian dan supervisi dalam pengajaran, dalam tahap pelaksanaannya dipantau oleh Direktur KMI yang saat ini dipegang oleh Ust. Drs. Abdurrahim Soleh dan dibantu guru-guru senior dan staf KMI.

Metode yang dignakan oleh guruguru KMI Darul Ma'rifat cukup bervariasi. Ada metode ceramah, latihan, demonstrasi, tanya-jawab dan penugasan. Dua metode atau lebih terkadang digunakan untuk mengajar satu mata pelajaran secara saling melengkapi. Pengajaran materi Fiqh bab praktek salat jenazah misalnya, tidak efektif jika hanya menggunakan metode ceramah, materi ini perlu diperkuat dengan metode demonstrasi dan tanya jawab agar pelajaran menjadi lebih menarik dan mencapai tujuan dengan lebih baik. Singkatnya, tidak ada satu materi yang diajarkan di KMI yang hanya menggunakan satu metode, dan hal ini dapat dibuktikan dalam buku-buku pedoman pengajaran di KMI Gontor.

\section{Penilaian dan Evaluasi Pembelajaran Bahasa Arab}

Evaluasi bagi santri KMI dibedakan menjadi tiga macam: yaitu (1). Evaluasi harian (biasa disebut muraaja'ah) baik lisan ataupun tulisan, (2). Evaluasi test hasil belajar yang dilaksanakan dua kali dalam satu tahun ajaran yaitu evaluasi pertengahan tahun dan akhir tahun, (3). Evaluasi belajar tahap akhir bagi santri kelas VI yang dibagi menjadi dua gelombang; yaitu tahap pertama untuk materi-materi pelajaran dari kelas I-V, 
tahap kedua untuk materi-materi yang dipelajari di kelas VI. Sebelum ujian akhir dilaksanakan biasanya mereka terlebih dahulu dikarantinakan di aula Pondok Modern demi menciptakan suasana belajar yang kondusif. Adapun teknik evaluasi yang dilaksanakan biasanya didahului dengan test lisan dan kemudian dilanjutkan dengan test tertulis berupa test uraian bebas dan terbatas, dan test obyektif dengan cara matching, completion, dan Short answer.

Proses belajar-mengajar dievaluasi secara terus menerus, sifatnya mingguan, bulanan, dan tahunan. Bagi para ustad, evaluasi itu dilaksanakan tiap Minggu dan biasanya dilaksanakan tiap hari Kamis siang yang diadakan di masjid Jami' Pondok, setelah sebelumnya diadakan pertemuan tiap-tiap utusan bagian pada rabu malam.

Pemerolehan Bahasa Arab di Pondok Pesantren Modern Gontor III Darul Mar'ifat Gurah Kediri

Penyampaian Kosakata Baru

Kegiatan ini dilakukan setiap hari, setelah salat subuh (05:00-05:20) dengan membaca Al-Qur'an sebelumnya, oleh seluruh kelas 1-4. Dan disampaikan oleh pengurus rayon siswa kelas 5, didepan rayon (Asrama) masing-masing. Santri diwajibkan untuk membuat kalimat lengkap dari setiap kosakata yang diberikan.

\section{Mahkamah Bahasa}

Kegiatan ini diadakan setelah baca Al-Quran diwaktu Maghrib, guna mengevaluasi kesalahan dan memberi hukuman kepada santri yang berbicara bahasa tidak resmi (Indonesia), dengan hukuman yang mendidik, seperti berpidato bahasa Arab, menterjemahkan makalah Indonesia ke bahasa Arab, dan menghafalkan teks atau uslub-uslub yang bermanfaat.

Laboratorium Bahasa alami (al-ma'mal al Arabi al-thabi'i)

Selain berupa sarana fisik, prasarana non-fisik yang sangat mendukung pengembangan pemerolehan bahasa santri di Pondok Modern Darul Ma'rifat antara lain adalah tersedia dan dibentuknya laboratorium bahasa alami berupa lingkungan wajib berbahasa pondok baik berupa bahasa Arab selama seminggu ( $A l$ Usbu' al-'Araby) dan bahasa Inggris (AlUsbu' al-Injilizy) dengan didukung oleh disiplin berbahasa yang ketat. Di Pondok Modern Darul Ma'rifat juga terdapat Clubclub kursus bahasa, setidaknya hingga kini ada 4 club, yaitu: Emerald (Club bahasa Arab dan Inggris), Diamond (Club bahasa Inggris). Al-Nahzhah (Club bahasa Arab), dan SBEC (Club bahasa Inggris).

Bagian Penggerak Bahasa, Mushrif Bahasa, dan Disiplin Berbahasa

Bagian penggerak bahasa (Central Language Improvement/CLI) adalah salah satu bagian dari OPM yang bertanggung jawab atas jalannya disiplin berbahasa baik Arab maupun Inggris serta usaha-usaha peningkatannya, yang antara lain melalui pengayaan kosakata, percakapan, kursuskursus, lomba (cerdas cermat, mengarang karya ilmiah dan cerpen, baca koran dan majalah serta kitab, debat, majalah dinding, menerjemah, drama, baca puisi, dan reportase olahraga), pemutaran kaset dan video serta $\mathrm{CD}$ (berita, lagu, percakapan, dan film), dan menerbitkan teks-teks dan buku. Bagian ini membawahi bagian penggerak bahasa di asrama-asrama santri serta Club-club kursus bahasa. Dalam hal ini dapat digambarkan sebagai berikut 


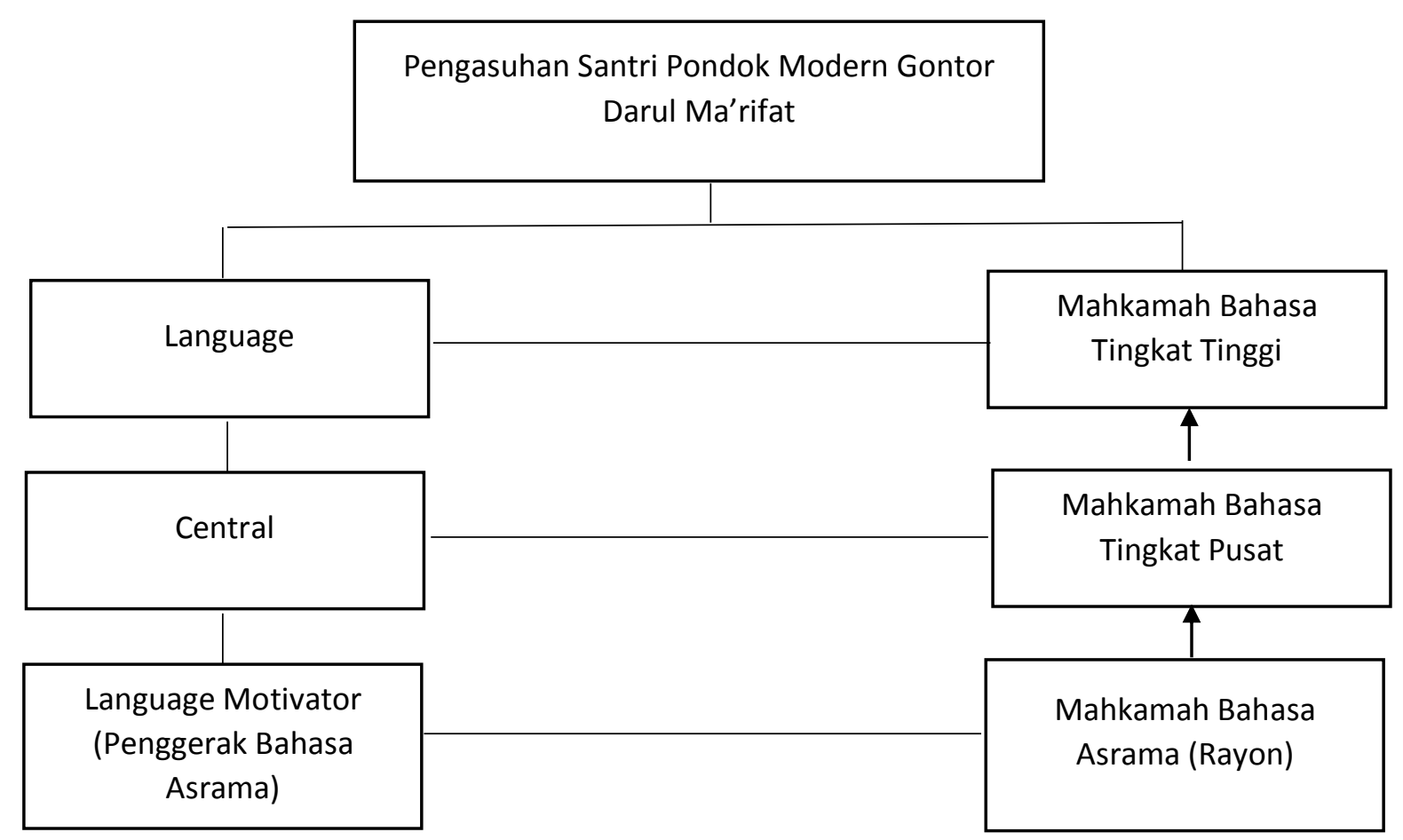

Bagan 1. Central Language Improvement/CLI

LAC (Language Advisory Council) merupakan lembaga yang ditangani langsung oleh ustadz dan bertanggung jawab terhadap terlaksanannya disiplin berbahasa dan peningkatan bahasa santri. LAC membawahi CLI (Central Languange Improvement) dan bagian penggerak bahasa di rayon-rayon.

Pelanggaran terhadap disiplin berbahasa dibagi menjadi dua jenis, yaitu pelanggaran ringan dan pelanggaran berat. Yang termasuk pelanggaran ringan antara lain: berbahasa Indonesia, merusak bahasa, tidak ikut kegiatan latihan muhadatsah, tidak ikut kegiatan pemberian Kosta kata dan sebagainya. Untuk para pelanggar kategori ini mereka biasanya diberi hukuman berupa; diberdirikan di depan masjid ba'da magrib hingga Isya', menghafal pelajaran atau surat-surat pendek, masuk pengadilan bahasa untuk diinterogasi, menjadi mata-mata (jasuus) bagi para pelanggar disiplin berbahasa, membuat insya (karangan), menghafal daily conversation (percakapan sehari-hari), menerjemahkan, dan lain sebagainya. Sedangkan yang termasuk pelanggaran berat dalam disiplin berbahasa antara lain; berbahasa daerah, merusak bahasa tiga kali berturut-turut, masuk pengadilan (mahkamah bahasa) lima kali berturut-turut dan sebagainya. Hukuman pelanggaran berat ini selain menerima tugas seperti disebutkan diatas juga mendapatkan sanksi yang lebih berat lagi.

Faktor Pendukung dan Penghambat Keberhasilan Pemerolehan Bahasa Arab di Pondok Modern Gontor Tiga Darul Ma'rifat Faktor-faktor pendukung keberhasilan, yaitu:

1. Adanya suri tauladan yang baik dari pada pendiri dan para pimpinan pondok, yaitu perjuangan mereka terhadap Islam dan demi umat sepanjang hidupnya yang tercermin 
dari rasa keikhlasan, keluasan hari, percaya diri, ukhuwwah Islamiyyah dan independensi.

2. Pimpinan pondok (pengasuh), para guru dan seluruh santrinya tinggal dalam satu kampus yang tertib dan teratur dengan disiplin berbahasa yang tepat dan terencana (terprogram).

3. Para guru seluruhnya adalah alumni Pondok Modern Gontor yang kesemuanya mempunyai arahan dan konsistensi yang sama dalam mempraktekkan bahasa Arab dan bahasa Inggris.

4. Adanya lembaga pengontrol bahasa sekaligus sebagai penggerak bahasa berjenjang dari dewan guru, organisasi pelajar, dan pengurus asrama. Ketiganya selain bertanggung jawab sisi kebahasaan, juga bertanggung jawab atas jalannya disiplin berbahasa dan maju mundurnya program kebahasaan.

5. Adanya motivasi santri yang tinggi dalam mematuhi aurat-aturan yang ada di Pondok sehingga tidak ada bagi santri untu bermalas-malasan dihadapan pada guru yang relatif ikhlas tanpa dibayar. Santri yang merasa tidak nyaman dengan peraturan-peraturan yang ada dipersilahkan untuk meninggalkan pondok untuk mencari pondok yang lebih cocok baginya.

6. Program-program pendidikan dan pemerolehan disusun secara teratur dan berlangsung selama 24 jam. Program-program kebahasa araban yang dimaksud antara lain: a. Pemebrian Kosta kata tiap pagi, b. Gerakan Tasyji'ul Lughah tiap Minggu, c, pemasangan Kosta kata di tempat-tempat strategis maupun di tiap benda yang dijumpai, d. Latihan pidato bahasa Arab tiap hari Kamis, e.
Latihan Muhadatsah asal 2 kali seminggu, f. Lomba-lomba kebahasaan, baik cerdas cermat, menerjemah menjadi reporter pertandingan olah raga, mengarang, drama arena dan sebagainya, g. Adanya Club-club kursus bahasa, dan lain-lain.

7. Adanya kepercayaan dari masyarakat luas terhadap pondok. Hal itu terbukti dari makin meningkatnya minat para orang tua tiap tahun untuk memasukkan anak-anaknya mondok di pesantren ini. Sehingga pondok terpaksa melakukan seleksi cara ketat dan terencana. Pondok juga selalu berusaha memperluas areal kampus dan menambah sarana dan prasarana yang ada demi meningkatkan pelayanan kepada masyarakat di bidang pendidikan ini.

8. Letak pondok yang jauh dari kota besar sehingga tercipta suasana kampus yang tenang dan tenteram yang sangat mendukung iklim proses belajar-mengajar yang teratur dan mandiri, relatif jauh dari pengaruh buruk budaya dan krisis akhlak.

Faktor yang menghambat keberhasilan pembelajaran dan pemerolehan bahasa Arab di PM. Gontor Tiga Darul Ma'rifat antara lain:

1. Adanya guru dan santri yang seluruhnya tinggal dalam satu asrama (kampus) terkadang menjadi pendukung kesuksesan pemerolehan bahasa, akan tetapi jika guru tidak mempunyai pengalaman yang lebih terhadap bahasa yang dipelajari maka akan membentuk iklim yang malas dan membosankan.

2. Pondok membutuhkan penambahan kader guru yang berpengalaman di bidang ilmu bahasa dan cara 
mengajarkannya, dengan syarat mereka adalah alumbi yang sudah mengajar di beberapa perguruan tinggi dan memperoleh pengalaman demi mengembangkan apa yang sudah ada dan dicapai oleh pondok selama ini.

3. Bahasa Arab yang hidup dan digunakan di Pondok Modern Gontor Tiga Darul Ma'rifat terpengaruh oleh dialek setempat dan membentuk sebuah budaya khusus yang tercermin dari percakapan antar santri.

4. Santri yang masuk di PM. Gontor Tiga Darul Ma'rifat mempunyai kualitas kemampuan yang lebih rendah daripada mereka yang masuk di PM. Gontor Pusat (Ponorogo). Hal ini dimaklumi karena keberadaan PM. Gontor Darul Ma'rifat merupakan pondok alternatif bagi mereka yang tidak lulus masuk di Gontor Pusat.

5. Kurangnya pemahaman santri akan manfaat dari disiplin berbahasa, sehingga kerap kali terjadi pelanggaran terhadap disiplin berbahasa itu meski pelanggaran tersebut berkategori ringan maupun sedang.

6. Kurangnya sarana penunjang berupa laboratorium bahasa, kaset-kaset, CD-CD berbahasa Arab serta jarangnya santri mendengarkan langsung pembicaraan seorang native speaker bahasa Arab, kecuali jika tamu dari Timur Tengah sengaja datang.

\section{PENUTUP}

\section{Simpulan}

Kegiatan pemerolehan bahasa Arab

yang ada di pondok tersebut adalah bersumber dari lingkungan dan kegiatan kebahasaan yang ada di pondok tersebut adalah bersumber dari lingkungan dan kegiatan kebahasaan yang ada di sana seperti adanya laboratorium bahasa alami berupa lingkungan wajib berbahasa pondok baik berupa bahasa Arab selama seminggu (Al-Usbu' al- 'Araby) dan bahasa Inggris (AlUsbu' al-Injilizy) dengan didukung oleh disiplin berbahasa yang ketat.

Adanya lembaga LAC (Language Advisory Council) yang merupakan lembaga yang ditangani langsung oleh ustadz yang bertanggung jawab terhadap terlaksananya disiplin berbahasa dan peningkatan bahasa santri. LAC membawahi CLI (Central Language Improvement) dan bagian penggerah bahasa dirayon-rayon kamar. Secara umum program kegiatan LAC itu adalah: memperbanyak pemberian mufradat (Kosa kata baru) setiap hari ba'da Shubuh (2-3 kosa kata), mengawasi pelaksanaan pelatihan Muhadatsah, mengadakan kursuskursu bahasa pada tiap-tiap Club bahasa, mengadakan Tasyji' al-Lughah (Pemberian motivasi berbahasa) untuk seluruh santri, program pensosialisasian Asaalib (Gaya/struktur bahasa) yang bagus pada seluruh santri dan mengadakan berbagai kegiatan pada hari-hari tertentu seperti Kontes drama bahasa Arab dan naskahnya antar asrama pada semester pertama (pertengahan tahun), lomba pidato bahasa Arab, Lomba menjadi komentator pertandingan sepak bola dengan bahasa Arab lomba menerjemahkan lagu-lagu ke bahasa Arab.

\section{DAFTAR PUSTAKA}

Cresswell, J. W. (1994). Research Design Qualitative \& Quanitative Approached. London: Sage Publication. 
Emzir. (2008). Metodologi Penelitian Pendidikan. Jakarta: Rajawali Pers.

Hidayatullah, A. (1991). Al-Lughah al'Arabiyyah fi Indunisia: Dirosatan wa Tarikhan. Disertasi. Fakultas Studi Ketimuran Jurusan Bahasa Arab Universitas Punjab Lahore Pakistan.
Mastuhu. (1994). Dinamika Sistem Pendidikan Pesantren. Jakarta: INIS

Nasution, H. (1996). Islam Rasional: Gagasan dan Pemikiran. Bandung: Mizan. 